\title{
O Exílio da Vida nas Margens do Mundo. Violência contra Trabalhadores Escravos em Mato Grosso (1970-1989)
}

\author{
Luciene Aparecida Castravechi ${ }^{1}$ \\ Vitale Joanoni Neto ${ }^{2}$
}

O recorte espacial desta pesquisa contempla a área da Prelazia de São Félix do Araguaia ${ }^{3}$ que está situada no curso médio Rio Araguaia localizada no Nordeste do Estado de Mato Grosso, fazendo divisa com os Estados do Pará, Tocantins e Goiás. A região é formada por quinze municípios, distantes em média $1.100 \mathrm{~km}$ de Cuiabá capital de Mato Grosso.

Para refletirmos a respeito das relações trabalhistas que envolvem a prática do trabalho escravo contemporâneo no Brasil, nos situamos a partir da década de 1970 quando o governo militar estabeleceu um amplo programa de (re)ocupação econômica da Amazônia brasileira. O governo militar estimulou a implantação de Projetos de Colonização e Agropecuários que favoreciam o grande capital, tendo sido

\footnotetext{
${ }^{1}$ Luciene A. Castravechi faz Doutorado em História pela Universidade Federal de Mato Grosso/ UFMT - Linha de Pesquisa: Territórios, Temporalidades e Poder. Graduada e Mestre em História pela mesma Instituição. Graduada em Gestão de Turismo pela Universidade Norte do Paraná - UNOPAR/Londrina. Atua principalmente nos seguintes temas: Colonização Recente de Mato Grosso, Migração, Trabalho Escravo Contemporâneo, Violência, Conflitos Agrários, Igreja Católica.

${ }^{2}$ Doutor em História pela Unesp de Assis. Professor do Departamento de História da Universidade Federal de Mato Grosso. Atua na Graduação e Pós-Graduação (Mestrado e Doutorado) do curso de História, privilegiando temas como Brasil e Mato Grosso na segunda metade do século XX, migração, trabalho, Igreja Católica. Coordena o Núcleo de Pesquisa em História e o Grupo de Pesquisa História, Terra e Trabalho.

${ }^{3}$ Conforme informações retiradas da carta pastoral de Dom Pedro Casaldáliga, o decreto de criação da Prelazia de São Félix do Araguaia, denominado de "Quo commodius", foi assinado por Paulo VI, aos 13 de março de 1970, estabelecendo os limites estritos da Prelazia de São Félix: "Ao norte, os confins da Prelazia de Conceição do Araguaia, que atualmente delimitam os Estados do Pará e Mato Grosso; ao leste os confins da Prelazia de Cristalândia, e ao oeste os da Prelazia de Diamantino, ou seja, os rios Araguaia e Xingu; ao sul a linha traçada em direção noroeste desde a confluência dos rios Curuá e das Mortes; e daí em linha reta até a confluência dos rios Couto de Magalhães e Xingu". A Prelazia de São Félix abrange $150.000 \mathrm{~km}^{2}$ dentro da Amazônia Legal, no Nordeste de Mato Grosso, e com a Ilha do Bananal (Casaldáliga, 1971: 4).
}

Brasiliana - Journal for Brazilian Studies. Vol. 2, n.2 (Nov 2013). ISSN 2245-4373. 
desenvolvidas naquela área atividades econômicas ligadas principalmente aos setores agrícolas e pecuários. Para a implantação dos projetos, as empresas receberam do governo grandes extensões de terras e incentivos fiscais para expansão das novas "fronteiras agrícolas" da Amazônia4.

A (re)ocupação do território amazônico tinha como objetivo gerar um modelo de desenvolvimento, bem como estimular a economia regional. Para tanto, esses projetos necessitavam de muita mão de obra, e a oferta na região era pouca, assim, os movimentos migratórios solucionaram esse problema, pois havia muitas pessoas a procura de emprego, ludibriadas por falsas promessas de enriquecimento fácil na Amazônia. A busca por terras, a sedução do garimpo, o trabalho, estimularam a vinda de muitas pessoas de várias partes do Brasil à procura do sonho do "Eldorado".

A devastação em larga escala da Amazônia teve início na segunda metade do século XX. As fazendas, financiadas pela SUDAM (Superintendência de Desenvolvimento da Amazônia), tinham em média 48 mil hectares, e só no Nordeste de Mato Grosso, havia, por exemplo, a AGROPECUÁRIA SUIÁ-MISSU S/A com 695.843 ha; a CODEARA com área de 196.497,19 ha; a AGROPASA, com 48.165 ha; a URUPIANGA, com 50.468 ha; a PORTO VELHO, com 49.994,32 ha, entre outras. Essas agropecuárias estão entre as primeiras denunciadas por Dom Pedro Casaldáliga ${ }^{5}$ por empregar o trabalho escravo (Casaldáliga, 1971: 9).

\footnotetext{
${ }^{4}$ A região Norte está inserida na Amazônia que compreende os Estados do Acre, Amapá, Amazonas, Pará, Rondônia, Roraima, Tocantins. A Amazônia Legal é acrescida pelo Estado de Mato Grosso e parte do Maranhão.

${ }^{5}$ Dom Pedro Maria Casaldáliga Plá nasceu em Balsareny, Espanha, no dia 16 de fevereiro de 1928. Ingressou na Ordem Claretian e foi ordenado sacerdote em 1943. Em 1968 foi para o Araguaia mato-grossense como missionário. Diante dos problemas encontrados, investiu tempo e energia na organização de indígenas e posseiros e nas denúncias das violações dos direitos humanos que estes e os peões sofriam. Em 1971 foi ordenado Bispo da Prelazia de São Félix do Araguaia. Em 2003, ao completar 75 anos, apresentou seu pedido de renúncia à Prelazia. Acerca da atuação de Dom Pedro Casaldáliga na Prelazia de São Félix do Araguaia. Ver: (Gomes, 2009), (Escribano, 2000).
}

Brasiliana - Journal for Brazilian Studies. Vol. 2, n.2 (Nov 2013). ISSN 2245-4373. 


\section{Trabalho análogo à escravidão}

Sobre o uso dessa mão de obra no Brasil temos que o Decreto Lei № 2.848, de 7 de dezembro de 1940 em seu artigo Art. 149 a caracterizou como crime previsto no Código Penal. O mesmo artigo foi reformulado pela redação dada pela Lei № 10.803, de 11 de dezembro de 2003, que passou a caracterizar o crime a partir da prática de "Reduzir alguém a condição análoga à de escravo, quer submetendo-o a trabalhos forçados ou a jornada exaustiva, quer sujeitando-o a condições degradantes de trabalho, quer restringindo, por qualquer meio, sua locomoção em razão de dívida contraída com o empregador ou preposto."

No tocante ao termo "trabalho forçado" a Convenção № 29 da Organização Internacional do Trabalho (OIT), o define como "todo trabalho ou serviço exigido de uma pessoa sob a ameaça de sanção e para o qual ela não tiver se oferecido espontaneamente".

A Campanha Contra o Trabalho Escravo ${ }^{6}$ movida pela Comissão Pastoral da Terra define que:

“Trabalho escravo é a redução de um ou vários trabalhadores à condição igual a de escravo, consistindo na privação da liberdade destes de sair de um lugar para outro, através da alegação de uma dívida crescente e permanente e, com efeito, há retenção de salário. Em casos extremos, há utilização de violência física ou psicológica contra o trabalhador para obrigá-lo a permanecer no local de trabalho, através de

\footnotetext{
${ }^{6}$ Esta Campanha contra o trabalho escravo à qual nos referimos é uma iniciativa da Comissão Pastoral da Terra (CPT). Consultar: www.cptnac.com.br.
}

Brasiliana - Journal for Brazilian Studies. Vol. 2, n.2 (Nov 2013). ISSN 2245-4373. 
"seguranças", "capangas", "fiscais" e outros que portam armas de fogo ou têm acesso fácil a elas." (Comissão Pastoral Nacional da Terra, 2007).

O Ministério do Trabalho, na Instrução Normativa no 1 de 1994, conceitua condição análoga à de escravo que se dá através de fraude, dívida e retenção de salário e documentos, ameaças e violência, com o fim do cerceamento da liberdade.

A superexploração do trabalhador ocasiona a imobilização da sua de mão de obra, que provoca o uso da coação física e/ ou moral, da restrição da capacidade de ir e vir dos trabalhadores e o impedimento de sua liberdade de oferecer a outros seus serviços. Desse modo, o emprego da violência nas relações trabalhistas é uma característica marcante nos casos de denúncias de trabalho escravo, o que causa indignação e preocupação, porém não mais estranhamento, pois estamos diante da banalização da violência.

O poder pessoal conferido ao grande proprietário de terras constitui-se como uma característica emblemática, na qual o fazendeiro juntamente com seus gerentes e capatazes tinham em suas mãos o poder de vida e morte sob seus empregados. Este fato contribuiu para que em suas propriedades se reproduzisse com facilidade "o tipo de dominação, repressão e violência características da dominação patrimonial" (Martins, 2009: 77).

A partir de $1970^{7}$ temos as primeiras denúncias de trabalho escravo no Brasil. Segundo José de Souza Martins, entre os anos de 1970 e 1993, o uso de trabalho escravo foi constatado em 431 fazendas no Brasil, desse total 308 estavam localizadas na Amazônia e 123 fora dela. Somadas essas denúncias em diferentes épocas, têm-se pouco mais de 85 mil trabalhadores escravizados; esse número pode estar inferior ao número

\footnotetext{
${ }^{7}$ A condescendência com a prática do trabalho escravo contemporâneo no Brasil foi quebrada pela Carta Pastoral de Dom Pedro Casaldáliga, intitulada Uma Igreja da Amazônia em conflito com o latifúndio e a marginalização social de 1971, no atributo de Bispo da Prelazia de São Félix do Araguaia em Mato Grosso.
}

Brasiliana - Journal for Brazilian Studies. Vol. 2, n.2 (Nov 2013). ISSN 2245-4373. 
real, pois os estudos realizados por Branford e Glock mencionam a estimativa de que no início de 1970, havia entre 250 mil e 400 mil peões trabalhando nas fazendas amazônicas na estação da seca. Uma única fazenda a Suiá-Missú empregou cerca de três mil peões na fase do desmatamento (Martins, 2009: 77).

As empresas estabelecidas na Amazônia, caracterizadas por uma produção mais avançada com o implemento de maquinários modernos, também foram responsáveis pela transformação e composição da mão de obra; sem corresponder no entanto, a melhoria de vida dos trabalhadores nessa nova área de expansão do capital. Evidenciando assim, que a modernização do campo não proporcionou obrigatoriamente uma humanização nas relações trabalhistas, surgindo novas modalidades de trabalho, sendo a mais comum para aquela região a peonagem, caracterizada por contratos por empreitas, tendo em lados opostos: o patrão e o empregado, o empreiteiro e o trabalhador denominado peão.

\section{Peões e gatos}

Os peões surgem a partir da entrada dos empreendimentos agropecuários na Amazônia. Conforme Borges (2002) o trabalho dos peões já nasce de forma precária e não como um trabalho que se precariza por conta de uma intensificação de exploração, como ocorreu ao longo da história. Essa atividade ocorre nos espaços de frentes pioneiras (Martins, 2009), tendo em vista que são áreas que estão sofrendo a inserção do capitalismo, bem como a abertura de fazendas. Vale ressaltar que em alguns casos a exploração destes trabalhadores se torna exacerbada ao ponto de se utilizar da violência nas relações de trabalho, configurando assim, um dos elementos que caracterizam a prática do trabalho escravo contemporâneo.

Brasiliana - Journal for Brazilian Studies. Vol. 2, n.2 (Nov 2013). ISSN 2245-4373. 
A situação de precariedade do trabalho do peão decorre da condição segundo a qual este indivíduo está inserido, qual seja a exploração da sua força de trabalho oriunda da necessidade da acumulação capitalista no campo, norteada por práticas laborais de caráter arcaico, como por exemplo, o uso do trabalho braçal em contraposição à alta tecnologia presente nestes empreendimentos, assim Borges nos mostra que a:

“Precarização e exploração do peão são, portanto, processos correlatos; um é decorrência do outro; há uma imbricação entre ambos: sem exploração não há precarização; esta constitui-se como decorrência da exploração que, ao atingir proporções mais avultadas, desencadeia esse processo. E, ainda mais, no caso do peão-de-trecho e dos "pobres antigos", a precarização deixa de constituir um processo próprio, decorrente, e apresenta-se como uma condição, um modo de vida, inserido substantivamente no processo de exploração." (Borges, 2002: $60)$.

Desse modo, essa condição de trabalho passa a ser naturalizada, ao passo que seu exercício geralmente ocorre em ambientes insalubres, distantes do seu lugar de origem, conforme o depoimento abaixo:

"A pessoa quando sai no trecho assim, acho que fica... eu acho que ele perde a vergonha pro mundo, mas com a família dele, toda a vida ele tem vergonha de voltá. Porque eu to aqui, mas eu acho que não tenho mais corage de voltá. Não fiz nada contra minha família, mas eu acho 
que não vô levá problema prá minha família mesmo" (Entrevista. Centro Pastoral para o Migrante, Cuiabá, 30 mar. 2007).

Nos relatos, esses trabalhadores demonstram que têm consciência de que na sua comunidade não há meios para sobreviver, restando-lhe a migração como uma alternativa para melhorar a vida e o trabalho, deixando para traz seus familiares com a ideia de ser algo temporário, mas com o passar do tempo, muitos tomam um caminho errante, de empreita em empreita, de fazenda em fazenda, pela busca de um salário melhor com a intenção de voltar para seu local de origem com a imagem de um trabalhador vitorioso.

Este ideal se esfacela, muitas vezes por não receber o pagamento do seu trabalho ou apenas uma parcela mínima dele, constituindo em outros lugares novos laços de sociabilidade à espera de um novo trabalho, uma nova chance de transformar a vida.

Sob a lógica do assalariamento e das relações de trabalho do mundo contemporâneo, o trabalho escravo é tido como prática condenável e ultrapassada. Mesmo considerando as muitas formas de precarização laboral, elas ainda permitem ao trabalhador sentir-se integrado, sonhar com o acesso ao mundo, ao consumo. Por ironia, é justamente na busca desse sonho que milhões de pessoas no mundo tornam-se objetos de consumo rápido e descartável.

Segundo Dom Pedro Casaldáliga, no início dos anos de 1970, no Nordeste do Estado de Mato Grosso, a mão de obra vinha do Nordeste brasileiro e de Goiás, os métodos de recrutamento eram promessas de bom trabalho e remuneração justa, feita geralmente por gatos $^{8}$ que assumiam os trabalhos nas fazendas sob o regime de

\footnotetext{
${ }^{8}$ Empreiteiro contratado para desflorestamento, feitura e conservação de pastos e cercas ou serviços para fazendeiros e empresas agropecuárias na Amazônia. Muitas vezes anda armado, trabalha com parentes e com uma rede de "fiscais", e são acusados de diversos crimes, inclusive homicídios. Em geral os mais violentos gozam de prestígio,
} 
empreita, uma forma de terceirização que pretendia isentar o fazendeiro das arbitrariedades que o gato cometia.

Os pagamentos eram efetuados como e quando o gato queria, muitas vezes apenas com vales, que eram uma maneira de prender o trabalhador, fato que gerava um comércio paralelo desses papeis, algum vendidos pela metade que valiam. Inútil denunciar tais crimes à polícia militar, frequentemente conivente com as irregularidades, ou quando não impotente para enfrentar os interesses daquelas empresas, conforme nos revela o documento abaixo:

“O delegado e a polícia local não estão salvos da influência todo poderosa dos ricaços locais e fazendeiros. São utilizados à serviço da escravidão. O delegado é comprado e não tem autoridade para dar voz de prisão a um poderoso e é intimidado em vez de intimidar. Se pede reforço para poder ser obedecido, ao chegar o reforço, não encontra mais nem um rastro do criminoso" (Documento do Acervo da Prelazia de São Félix do Araguaia - B08.1.2.48, 1971: 1).

Ao fim dos trabalhos, os peões eram largados nas vilas e tinham que arcar com as despesas de volta para seus Estados de origem. Considerados pelos moradores locais como inferiores, muitos assumiam essa identidade, passando a viver entre períodos de trabalho forçado nas fazendas (que podiam durar meses) e períodos de folga nas vilas à espera do próximo trabalho, permanecendo em locais públicos (praças, ruas, terminal, rodoviário), reconhecidos como pontos de concentração desse tipo de mão de obra e aos gatos e proprietários de terra recorriam quando precisavam de seu trabalho.

são considerados eficientes e podem prestar serviço por anos consecutivos para as maiores empresas (Figueira, 2004: 17).

Brasiliana - Journal for Brazilian Studies. Vol. 2, n.2 (Nov 2013). ISSN 2245-4373. 
O trabalhador migrante conhecido como peão do trecho ${ }^{9}$ é uma analogia ao pião de brinquedo que roda de um lugar para outro em busca de trabalho, seja qual for e onde for. Os documentos da Prelazia de São Félix demonstram que peão "é um termo usado na região para designar o trabalhador rural que trabalha nas derrubadas para a instalação de fazendas e projetos agropecuários aprovados pela SUDAM" (Documento do Acervo da Prelazia de São Félix do Araguaia - B08. 1.2.48, 1971: 01). O trabalho desses peões se dava da seguinte forma: com o gato ou "sub empreita", e por "time" ou em "sociedade".

Os gatos eram responsáveis pela contratação dos trabalhadores, pois agiam como mediadores no processo de contrato e aliciamento destes trabalhadores para o Nordeste do Araguaia. Eles eram responsáveis pelo controle dos trabalhadores, pela execução do serviço, funções estas que eram realizadas de modo informal e pessoal. Geralmente, os gatos pertenciam à mesma categoria social dos trabalhadores, e até mesmo realizaram trabalhos como peões. O trabalho realizado junto ao gato era a forma mais comum na região. O gato formalizava um contrato escrito com a fazenda, no qual constavam as exigências de execução da empreita, prazos, preços, etc. Incluía também a isenção explícita de assistência médica aos peões, sendo apenas responsáveis pelo tratamento da malária, mas que na maioria das vezes como nos expõe os documentos da Prelazia, as fazendas não se preocupavam com a saúde dos trabalhadores, tendo em vista que:

“Por conseqüência, não há seguro, nem assistência médica. As fazendas não são equipadas para atender os peões doentes ou acidentados. Não há médicos, nem enfermeiros. [...] Os medicamentos são insuficientes e

\footnotetext{
${ }^{9}$ Trabalhador fora do seu lugar de origem, desligado das antigas relações familiares sem construir novas, trabalha sucessivamente em fazendas atrelado a um ou a diversos empreiteiros. Entre uma empreitada e outra cria débitos em pensões e cabarés, mantendo-se preso à rede de endividamento e ao trabalho coercitivo. Em geral é analfabeto, sem qualificação profissional e tem problemas de alcoolismo. É também chamado de peão rodado (Figueira, 2004: 18).
}

Brasiliana - Journal for Brazilian Studies. Vol. 2, n.2 (Nov 2013). ISSN 2245-4373. 
pagos. [...] A maioria das mortes de malária é devido a falta de atendimento. Enviam quando já está passando. E o pior é que trazem casos graves para os povoados sem recursos, quando o caso só se resolve em Brasília ou Goiânia" (Documento do Acervo da Prelazia de São Félix do Araguaia - B08. 1.2.48, 1971: 1.2).

O gato fazia apenas um contrato verbal com o peão sobre as condições do trabalho, sendo estes em dois tipos diferentes:

“a) CATIVO: onde é tratado um preço por alqueire de serviço, e o peão arca com as suas despesas de alimentação, ferramentas e gastos assim chamados de "extraordinários" (cigarro, roupa, remédio...). O peão, ou o grupo de peões, trata com alguém a comida, mas todas as mercadorias são compradas do gato, o único com autorização para comprar do armazém da fazenda.

b) LIVRE: como o próprio nome diz, o preço tratado com o gato, o peão recebe livre de quaisquer despesas. O gato é que providencia então a alimentação e leva a bóia no serviço. O contato livre é sempre a metade do trabalho cativo. Assim, por exemplo se a juquira é paga $\$ 1000,00$ por alqueire na forma cativo, na forma livre, o peão recebe $\$ 500,00^{\prime \prime}$ (Documento do Acervo da Prelazia de São Félix do Araguaia - A17. 3.16, 1978: 29-30, 39).

A outra forma de trabalho realizado nos empreendimentos agropecuários se dava através da modalidade conhecida por "time": 
“Nesse esquema, um grupo de peões trabalham como associados (em sociedade) na empreita. Um representante faz o contrato escrito com a fazenda, (funciona como o gato), mas concretamente ele é um peão pois trabalha diretamente na produção. Fazem rodízio pra fazer a comida e o saldo é dividido equitativamente, a cada um competindo pagar os seus extraordinários. Os times são formados em média com 5 peões e no máximo 8" (Documento do Acervo da Prelazia de São Félix do Araguaia - A17. 3.16, 1978: 30.39).

Os códigos que regulam as relações de trabalho, tanto para trabalhadores como para empregadores não estavam presentes no cotidiano dos gatos, conforme Bruno e Vieira "que organizam sua relação com os trabalhadores baseados na experiência, onde predomina a naturalização da exploração do trabalho e o desrespeito às leis trabalhistas" (Bruno; Vieira, 2011: 14). O gato impõe-se de modo pessoal através de ameaças física e moral, configurando o crime contra a dignidade humana, pois os trabalhadores estavam sujeitos à violência, coação e humilhação.

\section{Escravidão por dívida}

Outra prática recorrente nos empreendimentos agropecuários no Araguaia relatado na documentação da Prelazia de São Félix, diz respeito à escravidão por dívida contraída nos armazéns das fazendas:

“Só podiam comprar no armazém local da Companhia. O empreiteiro, chefe do "time", retirava o que julgava necessário à manutenção do grupo. Só ele tinha contato com a empresa. Distribuía o material aos 
peões e anotava num caderno particular, a seu bel prazer. Nem $o$ direito de saber o quanto devia ou havia ganho o peão tinha" (Casaldáliga, 1971: 112 grifo do autor).

Em outro documento elaborado pela Prelazia encontramos uma denúncia sobre as condições dos peões nas fazendas da região, demonstrando que a "escravização e exploração dos peões são os armazéns onde o trabalhador é obrigado a comprar tudo que necessita. Os preços das mercadorias são exorbitantes, reavendo assim todo o salário do peão" (Documento do Acervo da Prelazia de São Félix do Araguaia - B08. 1.2.48, 1971:1).

Através da escravidão por dívida o trabalhador tem a sua liberdade extraída por meio de "mecanismos de endividamento artificial e formas de controle e repressão, geralmente envolvendo violência física e confinamento, para assegurar que o trabalhador não escapará e submeterá ao trabalho até que a tarefa seja concluída" (Martins, 1999: 162).

A dívida a que o trabalhador estava submetido era decorrente de três tipos de despesas debitadas a ele: o "abono", as despesas de viagem e o "fornecimento". O "abono" era um adiantamento recebido no momento do aliciamento do trabalhador, essa quantia geralmente era utilizada para suprir as necessidades da família enquanto a sua ausência ou para as despesas do próprio trabalhador durante a espera de um novo trabalho. Neste período muitos trabalhadores gastavam seu dinheiro com diversão em bares e zonas de prostituição próximas aos espaços de recrutamento (Esterci, 1987: 102).

As despesas da viagem eram cobradas dos trabalhadores, e estavam incluídos os gastos de transporte, alimentação e remédios. Os gastos com o "fornecimento" procediam dos produtos (cigarro, alimentos, instrumentos de trabalho) adquiridos pelos trabalhadores durante o período do serviço e de acordo com o tipo de trabalho 
assumido com o gato - cativo ou livre. O trabalhador enquanto não liquidava a sua dívida sabia que não era livre para vender a sua força de trabalho, e tinha a percepção de que quanto mais intensificasse sua força de trabalho e diminuíssem drasticamente os gastos, ainda assim corria o risco de não eliminar a dívida que o aprisionava.

Entretanto, essa percepção não suprimia a ilusão de saldo, pois apesar das experiências negativas em trabalhos anteriores, em outros casos se conseguia adquirir os saldos, mas raramente um trabalhador admitia que obtivesse saldo suficiente para voltar para seu local de origem. O fato decorre do compromisso assumido com a sua família, seja este um jovem solteiro ou um homem casado que para suprir a sua ausência almejava levar para casa uma recompensa material de grande valor. $\mathrm{O}$ fracasso da viagem pode provocar em muitos trabalhadores a vergonha de voltar para sua família e perpetuar o seu deslocamento através da constituição de uma nova família nos lugares de trabalho (Esterci, 1987: 104).

“... se o senhor parar a ouvir a história dos pé inchado...que chama pé inchado... Todos eles têm uma história e toda uma historia derrotada que não pode mais volta pra trás. Eu to aqui há um ano e oito mês sem vê meu filho, minha mulher, minha filha, ta vivendo de favor, mas eu volta pra lá desse jeito com o saco nas costa? Volto não. Depois que sai, não. É melhor não saí, fica em grupo ou... depois que sai e voltá com problema, não" (Entrevista. Centro Pastoral para o Migrante, Cuiabá, 30 mar. 2007).

Segundo Esterci (1999) a dívida corrobora com a usurpação da liberdade do trabalhador, e é a expressão da sua superexploração, além de estar muitas vezes associadas à percepção que os trabalhadores têm da relação com os patrões. A dívida não é 
questionada, mas sim a ausência de controle sobre os cálculos, a soma total e a composição desta. $\mathrm{O}$ reconhecimento da dívida torna seu pagamento uma questão de honra. Esses trabalhadores não saem da fazenda devendo.

“Apesar disso, fui trazido para São Félix. Aqui o farmacêutico Limoeiro me tratou. Voltei para a fazenda a fim de pagar a dívida de farmácia e pensão: Cr\$ 327;00. Era impossível eu saldar tal dívida, pois da Tamakavy nada recebi, mas só ganhei dívida.

O chefe de meu "time" rogou para que me perdoassem a dívida, mas não quiseram ouvir. E até me ameaçaram de por no picadão, isto é, voltar a pé. O chefe de minha turma pagou a minha dívida.

Tornei voltar a São Félix e tenho que pagar a dívida ao responsável de meu "time". Agora não sei o que fazer. Estou doente há 35 dias e não estou em condições de trabalhar e se voltar à fazenda a maleita me mata" (Documento do Arquivo da Prelazia de São Félix do Araguaia B08. 1.2.41, 1971: 1).

A autora ainda afirma que a dívida do trabalhador não está apenas restrita aos préstimos materiais, esta também se traduz em dívida moral de tal sorte que o trabalhador não presta apenas o trabalho compulsório, mas tem também um elo de compromisso e lealdade com o patrão. Desse modo, a relação de exploração pode ser pensada ao mesmo tempo como relações de dominação, as quais podem ser analisadas através da interação entre os dois polos nos quais os motivos, os valores e as estratégias dos dominados têm um lugar importante; assim, "falar em dominação implica pensar que há expectativa de cumprimento de obrigações recíprocas ainda que desiguais, que 
há espaço para negociação e que a relação se sustenta a partir de algum tipo de legitimidade que lhe é conferida" (Esterci, 1999: 103).

No entanto, na escravidão contemporânea o uso da violência é tão arbitrário e o descumprimento dos acordos é tão expressivo, que a aceitação dos dominados parece não mais importar categoricamente. $\mathrm{O}$ interesse entre os polos da relação está de tal modo ausente, que os elementos que configuram a dominação e legitimação não mais se empregam. Lembrando que a prática da dominação não exclui absolutamente o uso da violência, mas, ao ser empregada, a violência deve estar de acordo de alguma forma com as regras sociais. $\mathrm{O}$ que fica evidente nas inúmeras denúncias de trabalho escravo contemporâneo é a ação predatória, o negócio em curto prazo, em que não há perspectiva de lealdade futura por parte dos empregadores, mas apenas o anseio de lucros imediatos (Esterci, 1999: 103).

“O que eu sinto pode passar cem anos eu não esqueço não, é humilhante, é duro né? É ruim você dizer eu vou embora e o cara dizer trabalha ou apanha. E ser ameaçado, você trabalhar com uma arma apontada para você e uma pessoa dizer que vai bater se você não trabalhar, não importa se você está doente." (Depoimento apud Souza, 2009: 144).

Esterci afirma que muitos gatos fugiam com a remuneração dos peões, além de "roubar na medida das tarefas, cobravam preços extorsivos pelas mercadorias, colocavam nas contas itens por eles não consumidos, subtraíam pelo montante pago pela empresa, porcentagens julgadas excessivas, cobravam itens, como remédios, por exemplo, que não deveriam ser cobrados" (Esterci, 1987: 102). 
Nessa passagem, a autora expõe as estratégias utilizadas pelos gatos e outros intermediários para burlar o já pequeno ganho dos trabalhadores (peões). Os capatazes, gerentes ou administradores dessas empresas rurais, frequentemente tinham conhecimento dessas arbitrariedades, mas consideravam-se isentos de responsabilidade sobre tais ações, uma falsa impressão que caia por terra quando, revoltados, os peões reagiam ao logro e cercavam a sede das fazendas, ameaçavam fisicamente os responsáveis ali presentes e obrigavam a revisão nos seus pagamentos ou a efetivação dos mesmos.

No relatório elaborado pela Prelazia os trabalhadores demonstram sua indignação por não terem seu pagamento recebido devido à fuga do gato com o dinheiro da empreita:

“그/Faz. CODEBRA - o gato Paulo Magalhães fugiu com o dinheiro de uns 250 peões. Cerca de 120 deles, situaram-se em volta da sede, exigindo o pagamento e prometendo queimar a sede caso não fossem atendidos. Na época, era gerente, o próprio informante, que pelo rádio comunicou os donos. Esses se recusaram a atender a reivindicação. Um ou dois dias depois, um dos proprietários apareceu com a polícia querendo identificar os cabeças, que eram cerca de 5. O gerente conseguiu aconselhar a pagar, no que foi atendido.

74/Faz. SUIA MISSU - o mesmo gato acima repetiu a façanha envolvendo a soma de 110 mil cruzeiros e perto de 500 peões. Os peões tomaram a mesma atitude e a fazenda prontamente pagou" (Documento do Acervo da Prelazia de São Félix do Araguaia - A17. 3.16, 1978: 34 grifo do autor). 
Como podemos notar, em caso de fuga do gato com o dinheiro da empreita, os peões veem a fazenda como a responsável, embora o gato não esteja isento da culpa. Esta reivindicação dos trabalhadores é caracterizada pelo gerente da fazenda como uma "greve". Esta era um elemento de reação usado pelos peões e a sua eficácia decorria da força coletiva dos trabalhadores e da ameaça física que, coletivamente, provocavam naqueles que almejavam atacar. Com a prática da "greve" as empresas passaram a fazer o pagamento dos peões no escritório para depois acertar as contas com o gato, conforme o documento da Prelazia "Talvez como decorrência disso, certas fazendas como a BORDON, passaram a pagar os peões no escritório. Depois de acertada a conta destes, é o que o gato recebe o que lhe compete" (Documento do Acervo da Prelazia de São Félix do Araguaia - A17. 3.16, 1978: 34).

Além da atitude contestadora e ameaçadora dos trabalhadores demonstrada no documento acima, estes tinham outras estratégias para burlar suas tarefas como uma forma de resistência aos maus tratos que recebiam nas fazendas, dentre elas haviam casos de peões que por não aceitarem o regime de trabalho imposto pelo gato, acabavam abandonando o serviço, bem como "As "cobras", nome dado às tarefas que os peões deixam por fazer. Ele estuda o caminho mais comum que o fiscal vai fazer, e deixa, por exemplo, uma porcentagem da área sem derrubar" (Documento do Acervo da Prelazia de São Félix do Araguaia - A17. 3.16, 1978: 35).

Neste sentido, os trabalhadores não eram apenas agentes passivos no elo da corrente da escravidão contemporânea, eles como vimos, empreendiam estratégias de resistências para escaparem dos maus tratos dos gatos e seus capangas. Dentre estas, Neide Esterci (1987: 106) demonstra algumas reações desencadeadas pelos peões, caracterizadas como "malandragem", que como vimos nos documentos acima, implica em realizar o mau ou parcialmente um trabalho, prejudicando sua qualidade; ou a pressão dos peões contra empreiteiros e gerentes da fazenda, que pode ser exercida 
através de ameaças físicas conhecidas pelos trabalhadores como "greve"; como também as fugas que podem ser coletivas ou individuais, muitas delas ocorrem mesmo antes de chegarem às fazendas: "Já em meio de caminho, muitos peões desgostosos com "João Dentista" que não cumpria as promessas feitas, fugiram, pulando do caminhão durante a noite com o veículo em movimento ${ }^{10 \prime}$ (Documento do Arquivo da Prelazia de São Félix do Araguaia - B08. 1.2.41, 1971: 1).

Dom Pedro relata em sua carta pastoral a situação dos trabalhadores trazidos pelas empresas para o trabalho temporário. No trecho retirado da carta podemos observar as más condições de trabalho e a violência a qual o trabalhador estava submetido.

"São geralmente os peões gente nova. [...] Iludidos quase sempre a respeito do pagamento, do lugar, das condições de trabalho, do atendimento médico. Tendo que pagar até a viagem - contratado e estipulado num a posteriori decepcionante e forçado. Em sistema de empreitada que significa submeter-se, além do dono e seu gerente, às fraudes e abusos dos empreiteiros. Já na mata das fazendas, sem possibilidade de saída. Fechados no 'inferno verde'. Controlados por pistoleiros e 'gatos'. Atacados pela malária, quase sem exceção. Com o fígado e o baço inchados. Mortos muitos deles pela malária, acumulada às vezes, nas diversas espécies de doença. Sem medicamentos; ou com medicamento pago e insuficiente. E atendidos tarde, já sem esperança. Contra todas as promessas. Comida fraquíssima: arroz, feijão e carne seca. Nos armazéns das fazendas compram-se as mais elementares mercadorias

\footnotetext{
${ }^{10}$ Figueira demonstra que o trabalhador que emprega tal ato é conhecido como peão bola: aquele que, no transcurso da viagem para a fazenda, escapa, pulando do carro e rolando no mato (2004: 18).
}

Brasiliana - Journal for Brazilian Studies. Vol. 2, n.2 (Nov 2013). ISSN 2245-4373. 
a preço alto. E até venderam-se amostras gratuitas de medicamentos. Sem pagamento nenhum, muitas vezes, depois de meses de empreitada, os peões acabam o serviço devendo a fazenda! Saem fugindo da morte, por doença. Pelas matas. A pé, léguas, dias. Perseguidos. Atirados. E mortos. 'De morte morrida ou de morte matada'. Perdidos para sempre, o nome e o cadáver. Ameaças de armas, nos escritórios de algumas fazendas para aceitarem já fatalmente as inesperadas condições como fato consumado." (Casaldáliga, 1971: 106. grifo nosso).

O relato acima nos mostra elementos que configuram a prática do trabalho escravo contemporâneo. Os fragmentos em destaque elucidam os atos que apontam para tal fato, como a vigilância dos pistoleiros e de gatos, a compra dos alimentos nos armazéns das empresas e a falta de pagamento, essas ações nos expõem as formas degradantes as quais estavam sujeitados esses trabalhadores.

Conforme Martins (2009) as informações acerca do uso de trabalho escravo nas fazendas na Amazônia foram fornecidas pela Polícia Federal, como também por membros da Igreja Católica através do trabalho da CPT, a qual organizou um espesso arquivo de dados sobre o assunto, como por exemplo, em São Félix do Araguaia, onde os sacerdotes e agentes da pastoral coletaram e anotaram depoimentos desses foragidos, de modo a viabilizar denúncias e solicitar a intervenção de autoridades.

Os conflitos agrários e a prática do trabalho escravo no espaço amazônico brasileiro se intensificaram na década de 1970 através da entrada das empresas agropecuárias. Em decorrência disso acentuaram-se os problemas agrários no campo e o uso da violência contra a população daquela região. Esta violência de caráter instrumental só foi possível pela concentração do poder nas mãos de poucos (empresários, gatos, pistoleiros), que consequentemente perdeu a sua legitimidade, pois 
de acordo com Arendt (2009) o poder pertence a um grupo e nunca é propriedade de um indivíduo. Neste sentido, o poder desapareceu e cedeu espaço para o uso da violência que na fronteira é visto como algo corriqueiro inerente daquele lugar.

Em contrapartida, nesse período temos a atuação de uma "Igreja Progressista" juntamente com a figura de Dom Pedro Casaldáliga atuando na luta pela terra ao lado dos excluídos, bem como defendendo os direitos de trabalhadores submetidos em situações de trabalho escravo, desnaturalizando as relações de violência nas quais estes estavam inseridos.

A luta contra o uso do trabalho escravo foi particularmente importante. Com muita facilidade os moradores da região, acostumados a uma rotina de trabalho extenuante e a uma vida bastante regrada, naturalizavam a superexploração e não lhes causava nenhuma estranheza a falta de direitos. Como muitas das vezes, esses peões estavam a serviço das empresas desmatando áreas de uso comunal, quando não bebendo nas vilas e cidades e mexendo com as mulheres moradoras locais, as famílias radicadas ali, os viam com indiferença ou mesmo como antagonistas.

Em sua carta pastoral de 1971, Casaldáliga propõe uma nova forma de ver tal fato, faz uma longa e dura denúncia e inicia um consistente trabalho pastoral na Prelazia que começa primeiro por desnaturalizar tal violência, depois construindo uma rede de solidariedade entre trabalhadores migrantes e a Igreja local e num momento posterior buscando formas de garantir direitos junto a grupos de pressão sobre as esferas do poder institucionalizado, fosse a Comissão Pastoral da Terra, ou organismos internacionais como a Organização Internacional do Trabalho que cobravam do estado brasileiro providências contra essa situação visando assegurar aos habitantes locais o acesso aos seus direitos à terra, à vida, ao trabalho, à liberdade, à justiça.

Brasiliana - Journal for Brazilian Studies. Vol. 2, n.2 (Nov 2013). ISSN 2245-4373. 


\section{Considerações Finais}

Vemos no Araguaia, em todos os quinze municípios que integram a Prelazia de São Félix, uma História de ocupação pelos não índios que remonta pelo menos ao início do século XX, mas não se observam ações do governo federal ou estadual para se fazer presente naquela região. O Estado atua de modo muito incipiente em alguns municípios por meio de escolas e postos de saúde, poucos e precarizados e de destacamentos policiais.

O Brasil vivia tempos de ditadura e a outra face desse Estado que aparecia para aquelas pessoas era a do monopólio da violência através da repressão. Esta ação demonstra o que Arendt (2009) avalia como perda de poder. Para a autora o uso da violência destrói a relação do poder, visto que o lugar ocupado por um elimina o outro. A violência alcança a sujeição do indivíduo através da repressão e o poder a partir do consentimento proveniente do acordo inicial entre homens livres e iguais, assim, a violência se diferencia do poder pelo seu caráter instrumental, ao passo que esta se torna justificável quando se impõe com uma finalidade a ser atingida. Portanto, se o poder advém do consentimento, conclui-se que "jamais existiu governo exclusivamente baseado nos meios da violência" (Arendt, 2009: 67), lembrando que onde a violência atua de forma recorrente, o poder já se deteriorou. Para Arendt o poder está condicionado aos números, enquanto a violência até certo ponto pode agir sem eles, porque está amparada pela natureza instrumental, assim "a forma extrema do poder é Todos contra Um; a forma extrema da violência é Um contra Todos" (Arendt, 2009: 58).

Foi nessa condição que se instalou a Prelazia de São Félix do Araguaia em 1970. E foi também assim que chegaram à região as empresas e seus empreendimentos agropecuários no mesmo período. Aquelas pessoas viviam em posses, produzindo para 
o autoconsumo, em relações econômicas marcadas pela troca direta ou pela venda de poucos produtos para a aquisição do essencial. O Estado mal interferia na sua rotina.

É importante que se diga que não há sob nenhuma hipótese, a idealização da rotina daquela população local, mas fica claro que a partir da chegada das empresas agropecuárias e do estabelecimento de relações econômicas capitalistas, a correlação de forças mudou drasticamente. As empresas usavam as leis, se apoiavam em documentos escritos, faziam o discurso da institucionalidade, e por outro lado, exploravam a mão de obra escrava, invadiam terras indígenas e comunais, mantinham jagunços e pistoleiros sempre a postos. Mais ainda, tinham acesso à imprensa nacional e aos organismos de governo, quando não aos próprios responsáveis pelas pastas dos Ministérios, o que lhes era conveniente para justificar suas ações nos locais.

Vemos essa soma de elementos: incipiente presença do Estado; interesses econômicos; disputas pela posse da terra por grupos de produtores familiares, diferentes etnias indígenas e por empresas ligadas ao agronegócio; fatores importantes para o recrudescimento da violência. A quantidade e a intensidade dos registros de violência existentes na área da Prelazia de São Félix, não podem ser entendidas fora desse contexto. Quando o Estado não toma para si a prerrogativa da presença institucional, abre espaço para as disputas baseadas, como diz Arendt (2009: 68), no vigor individual. A existência de relações de trabalho análogas ao escravo, a presença da pistolagem, a grilagem de terras, os assassinatos, o medo, o uso desmedido da força, essa exacerbação da violência apenas foi possível em razão da atrofia do poder institucionalizado.

Em relação à Prelazia de São Félix do Araguaia e a Dom Pedro Casaldáliga, cremos ter sido possível demonstrar que sua atuação foi importante no sentido de enfrentar essa violência, desnaturalizando o suposto poder autoatribuído por esses grupos econômicos e com isso, desmontando as práticas de exploração de migrantes 
como mão de obra, o uso indiscriminado dos jagunços e da pistolagem, e mesmo a instrumentalização da lei a seu favor.

A partir da Igreja Católica e da fé popular, a Prelazia conseguiu construir uma alternativa de organização aos povos indígenas e pobres da região, fazendo frente à força das empresas e daqueles que, aproveitando-se das circunstâncias criadas, agiam como gatos. D. Pedro pregou a "não violência", ou seja, fez uso de meios justos e pacíficos que apontaram para a possibilidade da construção de outra forma de organização daquela sociedade. Tal discurso estava em sintonia com a Teologia da Libertação. Ao colocar-se ao lado dos que sofriam as violências, foi possível escapar às armadilhas retóricas que possibilitavam sua legitimação e propor a defesa intransigente dos direitos daquelas pessoas, flagrantemente aviltados.

A luta contra o uso do trabalho escravo foi particularmente importante. Com muita facilidade os moradores da região, acostumados a uma rotina de trabalho extenuante e a uma vida bastante regrada, naturalizavam a superexploração e não lhes causava nenhuma estranheza a falta de direitos.

Enfim, procuramos demonstrar nesse trabalho que essa violência fartamente documentada ao longo dos últimos quarenta anos na Prelazia de São Félix do Araguaia, é tributária da entrada de empreendimentos agropecuários na região sobrepondo-se às terras indígenas, de uso comunal e às posses ali existentes; à mudança nas relações econômicas trazidas por essas empresas; ao estímulo à migração como forma de atrair para o local a força de trabalho necessária para o funcionamento das suas atividades; à redução desses trabalhadores migrantes à condição de peães; a superexploração da mão de obra dos trabalhadores dentro das propriedades rurais o que os relegou à condição análoga a de escravos.

Todas essas ações foram feitas ao longo desses quarenta anos ao custo de uma inquestionável opção pela vida, mesmo que isso tenha por vezes custado vidas. Mas 
como disse o próprio D. Pedro: De golpe com a morte, minha vida se fará verdade. Por fim terei amado!

\section{Referências}

Alves, Leonice Aparecida de Fátima e Gomes, Maria Henriqueta dos Santos. Murais do Araguaia: Uma primeira aproximação. In: Marluza Marques Harres e Vitale Joanoni Neto, orgs. História, Terra e Trabalho em Mato Grosso: Ensaios Teóricos e Resultados de Pesquisas. São Leopoldo: Oikos, Unisinos, Cuiabá: EDUFMT, 2009.

Arendt, Hannah. Sobre a Violência. Rio de Janeiro: Civilização Brasileira, 2009.

Borges, Maria Stela Lemos. A consignação da violência: a peonagem na Região de Três Lagoas - MS. Campinas: UNICAMP, 2002. Tese (Doutorado em Sociologia), Universidade Estadual de Campinas, Campus Campinas, 2002. Disponível em: < http://www.bibliotecadigital.unicamp.br/document/?code=vtls000240130\&fd=y>. Acesso em: 30 abr. 2011.

Bruno, Regina e Viera, Maria Antonieta. Representações de Trabalhadores, Gatos e Empregadores sobre o Trabalho Escravo. In: Ricardo R. Figuira e Adonia A. Prado, orgs. Olhares sobre a escravidão contemporânea. Cuiabá: EdUFMT, 2011.

Casaldáliga, Pedro. Uma Igreja da Amazônia em conflito com o latifúndio e a marginalização social. São Félix do Araguaia, 1971. (mimeo).

Castro, Sueli Pereira de. et. al. A colonização oficial em Mato Grosso: "a nata e a borra da sociedade". Cuiabá: EDUFMT, 1994.

Esterci, Neide. A dívida que escraviza. In: Comissão Pastoral da Terra. Trabalho Escravo no Brasil Contemporâneo. São Paulo: CPT/Loyola, 1999.

Esterci, Neide. Conflito no Araguaia: peões e posseiros contra a grande empresa. Petrópolis: Vozes, 1987.

Figueira, Ricardo Rezende. Pisando fora da própria sombra: a escravidão por dívida no Brasil contemporâneo. Rio de Janeiro: Civilização Brasileira, 2004. 
Joanoni Neto, Vitale. Fronteiras da crença: ocupação do Norte de Mato Grosso após 1970. Cuiabá: Ed. UFMT/Carlini Caniato, 2007.

Martins, José de Souza. “A escravidão nos dias de hoje e as ciladas da interpretação: reflexões sobre riscos da intervenção subinformada". In: Comissão Pastoral da Terra. Trabalho Escravo no Brasil Contemporâneo. São Paulo: CPT/Loyola, 1999.

Martins, José de Souza. Fronteira: a degradação do outro nos confins do humano. São Paulo: Contexto, 2009.

Souza, Maria Aparecida Martins. Retalhos de Vidas: Escravidão Contemporânea no Araguaia (1970-2005). Cuiabá: UFMT, 2009. Universidade Federal de Mato Grosso, Campus Cuiabá, 2009.

\section{Entrevistas:}

Entrevista. Centro de Pastoral para o Migrante, Cuiabá, 30 mar. 2007 - Acervo Núcleo de Pesquisa em História.

\section{Acervos Consultados:}

Acervo do Núcleo de Pesquisa em História - ICHS/UFMT.

Acervo da Prelazia de São Félix do Araguaia. 